\title{
EDITORIAL
}

\section{NUEVOS PARADIGMAS EVOLUTIVOS EN LA MEDICINA SIGLO XXI}

\author{
ENRIQUE MELGAREJO R. MD'. \\ ${ }^{1}$ Cardiólogo Electrofisiólogo, Editor Revista Med
}

La Especie humana como tal, ha demostrado a través de los milenios que es evolutiva. Es evolutiva no solo en su genotipo y en sus adaptaciones, sino también en sus conocimientos y cambios de paradigmas; lo que ayer era verdad (heliocentrismo, p. ej.), hoy es totalmente opuesto. Como Especie, estamos sometidos a riesgos, pero un tanto diferentes frente a otras especies.

Estamos sometidos a riesgos perennes de guerras, a desastres naturales, a hambrunas, a epidemias, a accidentes laborales y a enfermedades profesionales. Pero además, dentro de toda la escala zoológica, estamos sujetos al sufrimiento y al dolor, pues somos la única especie consciente de nuestra propia finitud. De ahí que la Medicina y la Filosofía, siempre han estado de la mano; la una trata de explicar quiénes somos y el porqué de nuestra existencia, y la otra, cómo hacer más llevadera nuestra existencia con el menor sufrimiento posible y tratando además de prolongar nuestros pasos sobre la tierra, con mejor calidad de vida y tratando de vencer a la enfermedad, pero jamás a la muerte.

La medicina es una invención del Hombre, que surgió como arte y ciencia, hoy más ciencia que arte. El humanismo es uno de los principios que distingue al Médico -lamentablemente cada vez menos- debido a la invasión tecnológica necesaria y como fruto del vertiginoso desarrollo del conocimiento que el hombre en su evolución ha logrado. Debido a este desarrollo y evolución de la Medicina, esta se ha tornado cada vez más marcadamente especializada (como algún filósofo dijo, saber cada vez más de menos). Fue así entonces como surgió la Pediatría para el cuidado del frágil y lento proceso del más frágil ser de las especies, en sus procesos de desarrollo desde el nacimiento hasta el inicio de su madurez: la adolescencia.

Luego surgió la Ginecología, porque existen diferencias en la genética, la arquitectura y la vasculatura entre los sexos, y posteriormente apareció la Geriatría, porque en la medida en que se envejece hay cambios en las actitudes, el comportamiento, en la fisiología y en lo cognoscitivo en la medida en que pasan los años, trastocándose la experiencia por el olvido con sus procesos degenerativos propios de la máquina humana en su lucha de todas sus estructuras, en contra el tiempo.

Aparece la Ortopedia y traumatología ante la vulnerabilidad del ser humano a los accidentes y a la agresión o a su autoagresión intra-especie. Aparece la Infectología para defendernos de la peste-que tanto socavó a la humanidad en la edad media-, y de otras condiciones infecciosas, incluyendo la resistencia bacteriana por el mal uso de antibióticos; surge la Psiquiatría para el entendimiento y mejoramiento de la percepción del individuo y su interacción frente al entorno. La Cardiología para entender el motor del cuerpo $-y$ de la vida-, la Neurología para tratar de entender la compleja neuroquímica, y la Medicina Interna, con su acepción holística, y la medicina llamada alternativa a todo lo tradicional. Y surgen otras especialidades, todas con un común denominador: aliviar el dolor y el sufrimiento.

Y este proceso evolutivo de la ciencia en sus diferentes necesidades aplicadas a través de la Especialización, aun no termina. P. ej., hoy día sabemos que las mujeres tienen mayor riesgo cardiovascular que el hombre y que se mueren más por estos problemas, después de la menopausia, por la pérdida de su escudo protector estrogénico (la ignorancia que mata); entre las razas, también hay diferencias médicas, como p. ej., que sus sistemas renina angiotensina-aldosterona y el sistema adrenérgico es diferente en afrodescendientes, y más concretamente, el manejo de la enfermedad hipertensiva y de la falla cardiaca también es diferente en esta raza. Últimamente hemos visto cómo los enfermos con SIDA se mueren más por problemas cardiovasculares por alteraciones del perfil lipídico inducidos por los medicamentos anti-SIDA. Hay además otros aspectos 
que vamos aprendiendo, como el nuevo concepto de Medicina de Géneros o de Sexos, ya que existen diferentes respuestas ante la terapéutica y al intervencionismo entre los mismos.

Hay además una desigualdad representativa en los mega-estudios con base en los cuales se aplica la Medicina Basada en Evidencia (las mujeres en edad fértil usualmente son excluidas en los estudios de intervención farmacológica, por miedo a las demandas ante eventuales efectos teratogénicos). Es por todo lo anterior que surgen nuevas áreas médicas como es el de Medicina de Géneros, Razas y Minorías, tendiente a agrupar estos nuevos conceptos, o mejor, las diferencias existentes entre estas poblaciones. Se hace necesario investigar, divulgar e instruir a la comunidad médica y a la población en lo que hasta hace muy poco era todo visto por la misma óptica.

Ya a nivel mundial existe la conciencia de las diferencias de los riesgos para las enfermedades cardiovasculares en las mujeres. Es así como la AHA (Asociación Americana de Cardiología), la ESC (Sociedad Europea de Cardiología), la CSC (Sociedad Canadiense de Cardiología) -entre otras- y actualmente la SCCyCC (Sociedad Colombiana de Cardiología y Cirugía Cardiovascular), todas han desarrollado campañas específicas a nivel científico y hacia la comunidad. Cada vez se investiga y se conocen más estas diferencias, tanto así que ya las Guías han cambiado frente a estas circunstancias.

Recientemente el Dr. Jaime Urdinola -connotado Ginecólogo-Endocrinólogo-y el suscrito publicamos con el apoyo de la SCCyCC y la FECOLSOG (Federación Colombiana de Sociedades de Ginecología y Obstetricia) el Libro "Riesgo Cardiovascular en la Mujer Menopaúsica" para dar a entender a la comunidad médica en general que la mujer multi-rol del siglo XXI se está enfermando y muriendo cada vez más de problemas cardiovasculares. La primera causa de mortalidad en la mujer no es el temido cáncer de seno. No. Por cada mujer con cáncer de seno ya hay diez sepultadas por infarto o por accidente cerebro-vascular. Sin embargo, la mujer colombiana piensa que el infarto es la sexta causa de su mortalidad. Y también recientemente la SCCyCC creo el Comité de Cardiología de Géneros, Razas y Minorías para estimular a nuestra comunidad científica a desarrollar los conocimientos en ésta nueva área a través de la investigación y difusión, al igual que trazar políticas de prevención.

La Facultad de Medicina de la Universidad Militar Nueva Granada a través de su Revista Med, a partir de este número con el artículo "Enfoque de la paciente embarazada con enfermedad valvular cardiaca" abre un espacio específico en este tópico, para que quienes estén interesados en esta nueva área, se vinculen a través de la investigación, reflexiones o revisiones con el objetivo de expandir el conocimiento de las diferencias entre sexos, razas y minorías. Las páginas están abiertas y el Mundo Médico esperando cambiar paradigmas, fruto de la necesaria evolución, que como Especie y como individuos, debemos de realizar para dejar el planeta un tanto mejor a como nos lo dejaron o como lo encontramos. Y esa es nuestra obligación como Médicos. 


\title{
EDITORIAL
}

\section{NEW EVOLVING PARADIGMS IN THE XXI CENTURY MEDICINE}

\author{
ENRIQUE MELGAREJO R. MD ${ }^{1}$. \\ ${ }^{1}$ Cardiólogo Electrofisiólogo, Editor Revista Med
}

The human species has evolved through out the years where evolution took place not only in its genotype and adaptation, but also in their knowledge and paradigm shifts. Those knowledge that was thought to be true yesterday (e.g. heliocentric) might be the opposite today. As a species, we are subject to risks, but somewhat different to other species. We are subject to perennial risks of war, natural disasters, famine, epidemics, industrial accidents and occupational diseases. Also, among all the zoological scale, we are subject to suffering and pain, because we are the only species which are aware of our own finitude. Hence, medicine and philosophy have always been hand in hand where firstly we tried to explain who we are and why we exist, and secondly, how to make our life more bearable with least suffering and also to extend our existence with a better quality of life and try to beat diseases while acknowledging the impossibility of defeating death.

Medicine is a human invention, which emerged as an art and as science and today it is considered more scientific than artful. Humanism is one of the values that distinguish the eminence of a medical practitioner, where nowadays unfortunately it is less than it should, due to the necessary technological invasion and as a result of the rapid development of knowledge that man has achieved in its evolution. Due to development and evolution, medicine has become increasingly specialized (as some philosopher said, knowing more about less). Paediatrics was born during this evolution process to care for the weak and of the slow process of growing up, from birth until the onset of maturity: the adolescence.

Later, Gynaecology appears because there are differences in the genetics, architecture and vasculature between both sexes. Then Geriatrics appeared, because as you get older there are changes in attitudes, behaviour, physiology and in the cognitive together with aging, commutating the experience by oblivion, which has its own degenerative processes of the human body in its fight against time.
Orthopaedics and Traumatology appeared as a respond to the human vulnerability to accidents, aggressions and to self-aggression. Infectology appeared to fend off plague, which undermined greatly to humanity in the Middle Ages, and other infectious conditions, including bacterial resistance by the misuse of antibiotics. Then Psychiatry came to understanding and improving the individual's perception and their interaction with the environment, Cardiology emerged to understand the body's engine, Neurology to try to understand the complex neurochemistry, Internal Medicine with its holistic sense, and the one called by everything traditional as Alternative Medicine. Other specializations emerged all of them with the aim of alleviate suffer and pain.

This evolutionary process of science applied to different needs through specializations, has not yet ended. For instance, today we know that women have higher cardiovascular risk than men and with an increased risk after menopause, due to the loss of the estrogens shield. Among races, there are medical differences as well, for example renin-angiotensin-aldosterone system and adrenergic system are different in Afro-descendants in comparison to other races. More specifically, the management of hypertensive disease and heart failure is also different in this race. Lately, we have also seen how AIDS patients died of cardiovascular diseases and more alterations in the lipid profile induced by anti-AIDS drugs. There are other aspects that we are learning, such as the new concept of Gender Medicine, as there are different responses to therapy and intervention between them.

There is also a significant inequality in the mega-based studies which apply the evidence-based medicine (women of childbearing age are usually excluded from studies of pharmacological intervention, for fear of lawsuits if any eventual teratogenic effect appears). It is for all the mentioned above those new medical areas such as Gender, Race and Minorities Medicine are surging; they aimed at bringing together these new concepts, or rather, the differences between these populations. 
It is necessary to investigate, publicize and educate the medical community and the public in general about the differences of what, until recently, was all seen under the same optics.

There is already global awareness of the differences in risk for cardiovascular disease in women. Hence, the AHA (American Heart Association), ESC (European Society of Cardiology), CSC (Canadian Society of Cardiology)-among others, and now the SCCyCC (Colombian Society of Cardiology and Cardiovascular Surgery), all developed specific campaigns to inform scientist and the general community.

It is more frequent to find research that acknowledges such differences so that the guidelines have changed accordingly with these circumstances.

Recently, the notorious Dr. Jaime Urdinola, a well known Gynecologist-Endocrinologist, and I published the book: "Cardiovascular Risk in menopausal women", with the support of the SCCyCC and FECOLSOG (Colombian Federation of Societies of Gynecology and Obstetrics) with the aim of partaking the medical community in general the multi-role women of the
$\mathrm{XXI}$ century is getting sick and is dying more than ever because of cardiovascular problems. The first cause of mortality in women is not the fearsome breast cancer. For every woman with breast cancer, there are ten who died of infarction or stroke. However, Colombian women think stroke is the sixth leading cause of mortality. Recently the SCCyCC created the Gender, Race and Minorities Cardiology Committee in order to encourage our scientific community to broaden the knowledge in this new area through research and promotion, as well as to contrive prevention policies.

The Medicine Faculty of the Military University "Nueva Granada" through its Journal Med, opens a specific space in this topic with the article: "Pregnant patient with heart valve disease, a methodological approach" seeking those who are interested in this new area, make their contributions through research, reflections or revisions aiming to expand the knowledge on the gender, race and minorities differences. Pages are open and the medical community is hoping to change paradigms consequences of evolution, since as species and as individuals, it is a must to do in order to give our descendants a better world, such is our duty as a medical practitioners. 


\title{
EDITORIAL
}

\section{NOVA PARADIGMA EVOLUTIVO EM MEDICINA SÉCULO XXI}

\author{
ENRIQUE MELGAREJO R. MD. ${ }^{1}$ \\ ${ }^{1}$ Cardiólogo Electrofisiólogo, Editor Revista Med
}

A espécie humana como tal, tem provado ao longo dos milênios que é evolutiva. É evolução, não apenas no seu genótipo e suas adaptações, mas também em seus conhecimentos e mudanças de paradigmas; então ontem era verdade (heliocêntrica, por exemplo.), hoje é o oposto. Como uma espécie, estamos sujeitos a riscos, mas um pouco diferente de outras espécies.

Estamos sujeitos a riscos permanentes guerras, catástrofes naturais, fome, epidemias, acidentes e doenças ocupacionais. Mas também em toda a escala zoológica, estamos sujeitos ao sofrimento $e$ à dor, porque somos a única espécie de consciência da nossa própria finitude. Assim, a medicina ea filosofia, têm sido sempre de mãos dadas; se tenta explicar quem somos e porque de nossa existência, e os outros, como tornar nossa vida mais suportável com o menor sofrimento possível e também a tentar alargar os nossos pés no chão, com melhor qualidade de vida e tentando vencer a doença, mas nunca a morte.

A medicina é uma invenção do homem, que surgiu como uma arte e ciência, hoje, mais ciência do que arte. O humanismo é um dos princípios que distingue o médico, infelizmente, cada vez menos, devido à invasão tecnológica necessária e, como resultado do rápido desenvolvimento do conhecimento que o homem alcançou em sua evolução. Devido a este desenvolvimento e evolução da medicina, isso tem se tornado cada vez mais especializados (como algum filósofo disse, saber mais e mais ou menos). Foi, então como surgiu a Pediatría para o cuidado do processo frágil e lento, do desenvolvimento desde o nascimento até o início da maturidade: a adolescência.

Então veio a Ginecologia, porque existem diferenças na genética, arquitetura e vascularização entre os sexos, e posteriormente apareceu Geriatria, porque à medida que envelhecem, há mudanças de atitudes, comportamento, fisiologia $e$ as alterações cognitivas na medida em que os anos passam, interromperam o experiência por esquecer os seus próprios processos degenerativos da máquina humana em sua luta por todas as suas estruturas, em função do tempo.

Ortopedia e Traumatologia aparecem como à vulnerabilidade humana aos acidentes a auto-agressão ou agressão das espécies. Infecciosas aparece como uma defesa contra a peste-que minou boa parte da humanidade na Idade Média-, e outras doenças infecciosas, incluindo a resistência bacteriana devido ao uso inadequado de antibióticos; a psiquiatria trata de compreender e melhorar a percepção do indivíduo e sua interação com o ambiente. Cardiologia para entender o motor do corpo -e da vida-, Neurologia tentando entender a neuroquímica complexo, e Medicina Interna, com o seu sentido holístico e medicina alternativa chamada de tudo tradicionais. E há outras especialidades, todas com um denominador comum: para aliviar a dor e sofrimento.

E essa evolução da ciência aplicada em diferentes necessidades através da especialização, ainda não acabou, por exemplo., sabemos agora que as mulheres têm maior risco cardiovascular do que homens y que morre por essas causas, depois da menopausia, pela perda do estrogênio (a ignorância que mata); entre as raças, existem diferenças médicos, como por exemplo, o seu sistema renina-angiotensina-aldosterona e sistema adrenérgico é diferente em ascendência africano $e$, mais especificamente, a abordagem da doença hipertensiva ea insuficiência cardíaca também é diferente. Ultimamente vimos como pacientes com AIDS morrem de doença cardiovascular pelas alterações no perfil lipídico induzidas por drogas anti-Aids. Há outros aspectos que aprendemos, como o novo conceito de Medicina Sexo ou gênero, pois há diferentes respostas à terapia e intervenção entre eles.

Há também um representante da desigualdade nos estudos mega-base que se aplicam a medicina baseada em evidências (mulheres em idade fértil são geralmente excluídos dos estudos de intervenção farmacológica, por medo de processos antes de qualquer efeito terato- 
gênico). Por todo o exposto, que novas áreas médicas, como medicina Gênero, Raça e Minorias, destinada a reunir esses novos conceitos, ou melhor, as diferenças entre essas populações. É necessário pesquisar, divulgar e educar a comunidade médica e a população o que até recentemente era visto todos pela mesma luz.

Como não há a conscientização global sobre as diferenças de risco para doenças cardiovasculares em mulheres. Isto é como a AHA (American Heart Association), ESC (European Society of Cardiology), CSC (Canadian Society of Cardiology), -entre outros-e agora o SCCyCC (Sociedade Colombiana de Cardiologia e Cirurgia Cardiovascular), todos têm desenvolvido campanhas específicas a nível científico e para a comunidade. Cada vez mais pesquisa e conhecimento destas diferenças, tanto assim que, desde as orientações mudaram a face dessas circunstâncias.

Recentemente, o famoso Dr. Jaime Urdinola-Ginecologista-Endocrinologista, e abaixo-assinado publicado com o apoio da SCCyCC e FECOLSOG (Federação Colombiana de Sociedades de Ginecologia e Obstetrícia), o livro "Risco Cardiovascular em mulheres na menopausa" para transmitir à comunidade médica em geral as mulheres multi-função século XXI estão adoecendo e morrendo de mais e mais problemas cardiovasculares. A primeira causa de mortalidade em mulheres não é o temido câncer de mama. Não. Para cada dez mulheres com câncer da mama existe uma morte por causa de infarto ou derrame. No entanto, acho que as mulheres colombianas AVC é a sexta causa de mortalidade. E recentemente, eu SCCyCC Cardiologia Comitê de Gênero, Raça e Minorias, para encorajar os nossos cientistas a desenvolver o conhecimento nesta área através de novas pesquisas e divulgação, para tornar a política de prevenção.

A Faculdade de Medicina da Universidad Militar Nueva Granada, através da sua Med Journal, a partir desta questão com o artigo "Abordagem do paciente grávida com doença cardíaca valvular" tem aberto um espaço específico sobre este tema, para os interessados nesta nova área, estão ligados através de pesquisa, reflexão ou análise de forma a ampliar a consciência das diferenças entre os sexos, raças e minorias. As páginas são abertas e os Médicos do Mundo com a esperança de mudança de paradigmas, e o resultado da evolução necessária como espécie e como indivíduos, devemos tomar para deixar o planeta um pouco melhor quando deixamos ele ou como nós a encontramos. Essa é a nossa obrigação como Médicos. 